\title{
PENINGKATAN KEAHLIAN PROSES PENGELASAN ANAK-ANAK PUTUS SEKOLAH KOTA MALANG
}

\author{
Achmad Taufik, Aladin Eko Purkuncoro*, Arif Kurniawan, Taufik Hidayat \\ Fakultas Teknologi Industri ITN Malang \\ *Email: aladinssmart@yahoo.com \\ (Diterima 26-02-2020; Disetujui 23-03-2020)
}

\begin{abstract}
ABSTRAK
Keterampilan yang mandiri dapat dibina melalui pelatihan yang terus menerus secara periodik dengan pola pelaksanaan yang telah ditentukan oleh pemerintah berdasarkan tingkat kebutuhan masyarakat. Bagi industri kecil dan menengah di bidang permesinan dan konstruksi baja ringan, lingkup pekerjaannya tidak bisa lepas dari bahan logam (terutama baja). Hasil produk yang dihasilkan selalu berkaitan dengan penyambungan antar komponen logam, penyambungan antar komponen yang paling umum bisa dilakukan adalah dengan mur baut, keling maupun las. Dalam pengabdian masyarakat melalui pelatihan ini dapat memberikan informasi tentang tugas dan kewenangan pemeriksa pengelasan. Memberikan pemahaman tentang dasar perhitungan kekuatan sambungan las, yang kemudian dipusatkan pada pembacaan tabel. Memahami fenomena penyimpangan setelah proses pengelasan. Memberikan pemahaman tentang cara memperbaiki cacat pengelasan. Juga dalam pelatihan ini bisa mendapatkan proses pengelasan dengan menggunakan prosedur pengelasan, sehingga manajemen proses pengelasan bisa berjalan dengan baik.
\end{abstract}

Kata kunci: pelatihan, pengelasan, logam

\section{PENDAHULUAN}

Dalam menumbuhkembangkan kreativitas anak kita akan melakukan pengabdian masyarakat dengan mengadakan pelatihan proses pengelasan kepada anak-anak putus sekolah yang tergabung dalam Save Street Cild (SSC) dimana nantinya diharapkan dapat berdiri suatu workshop yang mampu dikelola secara mandiri. SSC merupakan komunitas peduli anak jalanan, dibentuk oleh anak muda, dikelola oleh anak muda dan bersifat independen, desentralis, juga kreatif, sesuai semangat muda. Fokus garapan dari SSC adalah anak-anak jalanan dan anak-anak marjinal (misal, anak dari kampung nelayan kumuh, kampung pemulung, dst). Dan advokasi (terutama pendidikan) anak-anak dan ibunya. Karena, anakanak dan ibunya adalah suatu kesatuan yang tidak bisa dipisahkan.

Ketrampilan yang mandiri dapat dibina melalui pelatihan yang terus menerus secara periodik dengan pola pelaksanaan yang telah ditentukan oleh pemerintah berdasarkan tingkat kebutuhan masyarakat. Bagi industri kecil dan menengah di bidang permesinan dan konstruksi baja ringan, lingkup pekerjaannya tidak bisa lepas dari bahan logam (terutama baja). Hasil produk yang dihasilkan selalu berkaitan dengan penyambungan antar komponen logam, penyambungan antar komponen yang paling umum bisa dilakukan adalah dengan mur baut, keling maupun las.

Sambungan dengan pengelasan, merupakan sambungan antar komponen yang praktis dan menghasilkan sambungan yang lebih ringan (dibanding mur-baut dan keling). Namun, kegagalan pengelasan sering dijumpai karena logam yang dilas tidak sesuai dengan elektroda 
yang digunakan, dan menyebabkan menurunnya kekuatan sambungan. Karena penanganan pekerjaan pengelasan harus dilakukan secara khusus (seperti: welding procedure dan operator yang bersertifikat), maka pengelasan menjadi pekerjaan yang sangat penting dan melibatkan lembaga sertifikasi.

Suatu upaya peningkatan ketrampilan anak adalah melalui pelatihan tentang pengelasan, dimana nantinya diharapkan dapat tercipta berdirinya suatu bengkel pengelasan yang dikelola oleh anak-anak putus sekolah secara mandiri.

Evaluasi terhadap hasil pelatihan dilaksanakan untuk mengetahui sampai sejauh mana serapan materi pelatihan yang diperoleh peserta, yang tercermin dari sikap trampil yang dimiliki oleh peserta pelatihan. Adapun proses evaluasinya dilaksanakan dengan cara melakukan test akhir pelatihan, yang terdiri atas tes teori dan tes praktek. Pelatihan ini bisa dirancang sedemikian rupa sehingga mudah dipahami oleh para peserta.

Pelatihan dalam pengabdian masyarakat ini dapat memberikan informasi tentang tugas dan kewenangan pemeriksa pengelasan, memberikan pemahaman tentang dasar perhitungan kekuatan sambungan las, yang kemudian dipusatkan pada pembacaan tabel, memahami fenomena penyimpangan setelah proses pengelasan, dan memberikan pemahaman tentang cara memperbaiki cacat pengelasan. Juga dalam pelatihan ini bisa mendapatkan proses pengelasan dengan menggunakan prosedur pengelasan, sehingga manajemen proses pengelasan bisa berjalan dengan baik; mereduksi tingkat kegagalan pengelasan, sehingga penggunaan bahan lebih efektif; dan meningkatkan mutu sambungan las.

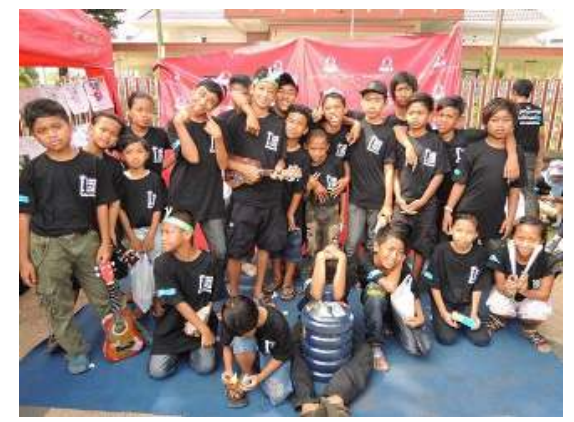

\section{Gambar 1. Anak-anak putus sekolah yang tergabung dalam SSC (Save Street Child)}

Anak putus sekolah adalah keadaan dimana anak mengalami keterlantaran karena sikap dan perlakuan orang tua yang tidak memberikan perhatian yang layak terhadap proses tumbuh kembang anak tanpa memperhatikan hak-hak anak untuk mendapatkan pendidikan yang layak. Anak terlantar diartikan sebagai anak yang orang tuanya karena suatu sebab, tidak mampu memenuhi kebutuhan anak sehingga anak menjadi terlantar (UU No 4 Tahun 1979). 
Dampak yang akan didapat dari anak yang putus sekolah berupa: (1) Wawasan/ilmu pengesahuan yang dimiliki oleh anak sangat minim, (2) Masa depan anak tidak jelas, (3) Menyebabkan banyaknya pengangguran di masa mendatang, dan (4) Di masa mendatang anak ini cenderung berpikiran lebih mementingkan adat/budaya daripada pendidikan, seperti halnya orang tuanya.

Salah satu pendekatan yang bisa digunakan untuk mengatasi permasalahan anak-anak putus sekolah yakni dengan memberikan penyuluhan berupa pelatihan kepada anak-anak putus sekolah yang tergabung dalam SSC untuk menciptakan suatu produk yang bernilai tinggi tentunya bermanfaat. Melalui pengabdian ini, diharapkan anak-anak dapat belajar tentang ilmu pengelasan. Selain itu, kita juga dapat meningkatkan kreativitas anak-anak tersebut, yang kedepannya diharapkan dapat menciptakan suatu bengkel secara mandiri.

Sifat-sifat khas bahan industri dikenal secara baik karena bahan tersebut dipergunakan untuk berbagai macam keperluan dalam berbagai keadaan. Sifat-sifat bahan yang diinginkan sangat banyak, termasuk: sifat-sifat mekanik (kekuatan, kekerasan, kekakuan, keliatan, keuletan, kepekaan takikan atau kekuatan impak, dsb), sifat-sifat listrik (hantaran listrik dielektrisitas, dsb), sifat-sifat magnet (permeabilitas, koersivitas, histrisis, dsb), sifat-sifat termal (panas jenis, pemuaian, konduktivitas, dsb), sifat-sifat kimia (reaksi kimia, kombinasi, segregasi, ketahanan korosi, dsb), sifat-sifat fisik (ukuran, massa jenis, struktur, dsb), sifatsifat teknologi (mampu mesin, mampu keras dsb), dan masih banyak lainnya (Surdia, 1984).

Berdasarkan definisi dari Deutche Industrie Normen (DIN), las adalah ikatan metalurgi pada sambungan logam atau logam paduan yang dilaksanakan dalam keadaan lumer atau cair. Definisi ini juga dapat diartikan lebih lanjut bahwa las adalah sambungan setempat dari beberapa logam dengan menggunakan energi panas (Wiryosumarto, 2000).

Pengelasan adalah suatu aktifitas menyambung dua bagian benda atau lebih dengan cara memanaskan atau menekan atau gabungan dari keduanya sedemikian rupa sehingga menyatu seperti benda utuh. Penyambungan bisa dengan atau tanpa bahan tambah (filler metal) yang sama atau berbeda titik cair maupun strukturnya .

Beberapa metode atau cara pengelasan telah ditemukan untuk membuat proses pengelasan dengan hasil sambungan yang kuat dan efisien. Pengelasan juga memberikan keuntungan baik itu dalam aspek komersil maupun teknologi. Adapun keuntungan dari pengelasan adalah sebagai berikut:

1. Pengelasan memberikan sambungan yang permanen. Kedua bagian yang disambung menjadi satu kesatuan setelah dilas. 
2. Sambungan las dapat lebih kuat daripada material induknya jika logam pengisi (filler metal) yang digunakan memiliki sifat-sifat kekuatan yang tinggi dari pada material induknya, dan teknik pengelasan yang digunakan harus tepat.

3. Pengelasan biasanya merupakan cara yang paling ekonomis jika ditinjau dari harga pembuatannya dan segi penggunaannya.

4. Pengelasan tidak dibatasi hanya pada lingkungan pabrik saja, tetapi pengelasan juga dapat dilakukan atau dikerjakan di lapangan.

Berdasarkan masukan panas (heat input) utama yang diberikan kepada logam dasar, proses pengelasan dapat dibagi menjadi dua cara, yaitu: (1) Pengelasan dengan menggunakan energi panas yang berasal dari fusion (nyala api las), contohnya: las busur (arc welding), las gas (gas welding), las sinar elektron (electron discharge welding), dan lain-lain, dan (2) Pengelasan dengan menggunakan energi panas yang tidak berasal dari nyala api las (non fusion), contohnya: friction stirr welding (proses pengelasan dengan gesekan), las tempa, dan lain-lain (Wiryosumanto, 2000).

Berdasarkan klasifikasi ini, maka pengelasan dapat dibagi dalam tiga kelas utama yaitu (Wiryosumanto, 2000):

1. Pengelasan cair adalah pengelasan dimana sambungan dipanaskan sampai mencair dengan sumber panas dari busur listrik atau sumber api gas yang terbakar.

2. Pengelasan tekan adalah cara pengelasan dimana sambungan dipanaskan dan kemudian ditekan menjadi satu.

3. Pematrian adalah cara pengelasan dimana sambungan diikat dan disatukan dengan menggunakan paduan logam yang mempunyai titik cair rendah. Dalam hal ini logam induk tidak ikut mencair.

Pengelasan dengan gas dilakukan dengan membakar bahan bakar gas yang dicampur dengan oksigen $\left(\mathrm{O}_{2}\right)$ sehingga menimbulkan nyala api dengan suhu tinggi $\left(3.000^{\circ}\right)$ yang mampu mencairkan logam induk dan logam pengisinya. Jenis bahan bakar gas yang digunakan asetilen, propan atau hidrogen, sehingga cara pengelasan ini dinamakan las oksiasetilen atau dikenal dengan nama las karbit (Fatchurahman, 2011).

Nyala asetilen diperoleh dari nyala gas campuran oksigen dan asetilen yang digunakan untuk memanaskan logam sampai mencapai titik cair logam induk. Pengelasan dapat dilakukan dengan atau tanpa logam pengisi.

Oksigen diperoleh dari proses elektrolisa atau proses pencairan udara. Oksigen komersil umumnya berasal dari proses pencairan udara dimana oksigen dipisahkan dari nitrogen. Oksigen ini disimpan dalam silinder baja pada tekanan $14 \mathrm{MPa}$. Gas asetilen $\left(\mathrm{C}_{2} \mathrm{H}_{2}\right)$ 
dihasilkan dari reaksi kalsium karbida dengan air. Gelembung-gelembung gas naik dan endapan yang terjadi adalah kapur tohor.

Bila dihitung ternyata $1 \mathrm{~kg} \mathrm{CaC}_{2}$ menghasilkan kurang lebih 300 liter asetilen. Sifat dari asetilen $\left(\mathrm{C}_{2} \mathrm{H}_{2}\right)$ yang merupakan gas bahan bakar adalah tidak berwarna, tidak beracun, berbau, lebih ringan dari udara, cenderung untuk memisahkan diri bila terjadi kenaikan tekanan dan suhu (di atas 1,5 bar dan $350^{\circ} \mathrm{C}$ ), dapat larut dalam massa berpori (aseton).

Karbida kalsium keras, mirip batu, berwarna kelabu dan terbentuk sebagai hasil reaksi antara kalsium dan batu bara dalam dapur listrik. Hasil reaksi ini kemudian digerus, dipilih dan disimpan dalam drum baja yang tertutup rapat. Gas asetilen dapat diperoleh dari generator asetilen yang menghasilkan gas asetilen dengan mencampurkan karbid dengan air atau kini dapat dibeli dalam tabung-tabung gas siap pakai. Agar aman tekanan gas asetilen dalam tabung tidak boleh melebihi $100 \mathrm{Kpa}$, dan disimpan tercampur dengan aseton.

Prisip dari pengelasan ini tidak terlalu rumit. Hanya dengan mengatur besarnya gas asetilen dan oksigen, kemudian ujungnya didekatkan dengan nyala api maka akan timbul nyala api. Tetapi besarnya gas asetilen dan oksigen harus diatur sedemikian rupa dengan memutar pengatur tekanan sedikit demi sedikit. Apabila gas asetilen saja yang dihidupkan maka nyala apinya berupa nyala biasa dengan mengeluarkan jelaga. Apabila gas asetilennya terlalu sedikit yang diputar, maka las tidak akan menyala.

Nyala hasil pembakaran dalam las oksi-asetilen dapat berubah bergantung pada perbandingan antara gas oksigen dan gas asetilennya. Ada tiga macam nyala api dalam las oksi-asetilen (Shaury, 2017):

a. Nyala asetilen lebih (nyala karburasi)

Bila terlalu banyak perbandingan gas asetilen yang digunakan maka di antara kerucut dalam dan kerucut luar akan timbul kerucut nyala baru berwarna biru. Di antara kerucut yang menyala dan selubung luar akan terdapat kerucut antara yang berwarna keputihputihan, yang panjangnya ditentukan oleh jumlah kelebihan asetilen. Hal ini akan menyebabkan terjadinya karburisasi pada logam cair. Nyala ini banyak digunakan dalam pengelasan logam monel, nikel, berbagai jenis baja dan bermacam-macam bahan pengerasan permukaan non-ferous.

b. Nyala netral

Nyala ini terjadi bila perbandingan antara oksigen dan asetilen sekitar satu. Nyala terdiri atas kerucut dalam yang berwarna putih bersinar dan kerucut luar yang berwarna biru bening. Oksigen yang diperlukan nyala ini berasal dari udara. Suhu maksimum setinggi 3.300 sampai $3.500{ }^{\circ} \mathrm{C}$ tercapai pada ujung nyala kerucut. 
c. Nyala oksigen lebih (nyala oksidasi)

Bila gas oksigen lebih daripada yang dibutuhkan untuk menghasilkan nyala netral maka nyala api menjadi pendek dan warna kerucut dalam berubah menjadi ungu. Nyala ini akan menyebabkan terjadinya proses oksidasi atau dekarburisasi pada logam cair. Nyala yang bersifat oksidasi ini harus digunakan dalam pengelasan fusion dari kuningan dan perunggu namun tidak dianjurkan untuk pengelasan lainnya.

\section{BAHAN DAN METODE}

Seperti halnya langkah pengelasan yang lainnya, las oksi-asetilin dipakai untuk menyambung dua sisi logam dengan permanen tanpa atau dengan bahan pengisi. Akan tetapi perlu untuk diketahui perlengkapan las oksi-asetilin membutuhkan mekanisme keselamatan kerja yang berbeda serta lebih ketat.

Las oksi-asetilin memakai nyala api hasil pembakaran gas asetilin serta gas oksigen (zat asam) untuk memanaskan sisi logam yang akan disambung serta mencairkan bahan pengisinya. Las oksi-asetilin banyak digunakan untuk pekerjaan perbaikan bodi otomotif serta pemotongan logam.

Waktu bekerja memakai las oksi-asetilin, operator las harus memahami mekanisme keselamatan kerja sebab sangatlah berpotensi memunculkan bahaya kebakaran atau ledakan. Bahaya kebakaran bisa dipacu oleh nyala api serta percikan bunga api yang mengenai beberapa bahan mudah terbakar. Sedang ledakan umumnya diakibatkan oleh kekeliruan dalam memakai perlengkapan las oksi-asetilin khususnya tabung asetilin serta pembakar.

Mekanisme keselamatan kerja pada saat memakai las oksi-asetilin mengutamakan pada tindakan pengamanan pada perlengkapan utamanya. Perlengkapan itu terbagi dalam tabung gas, regulator, pembakar, serta selang las.

\section{Tabung gas}

Tabung gas dipakai untuk menaruh gas (asetilin serta oksigen) yang dibakar secara bersama dengan formasi berbeda hingga menghasilkan nyala api. Tabung gas terbagi dalam satu tabung gas oksigen serta satu tabung gas asetilin.

Tabung gas asetilin berisi gas yang dimampatkan dengan volume 40 liter serta tekanan sampai 15 bar. Tabung gas oksigen sendiri bisa berisi gas sekitar 74,5 m3 dengan kadar oksigen murni 99,5\% serta tekanannya sebesar 151 bar. Aksi pengamanan yang dikerjakan ialah:

- Menghindari tabung gas dari semua jenis tipe minyak serta pelumas. 
- Membuat perlindungan tabung gas dari benda panas serta sinar matahari dengan cara langsung dan peluang bersentuhan dengan kabel listrik.

- Tempatkan tabung gas di tempat yang aman dari benturan atau pukulan benda keras.

- Tidak merubah, mencabut serta menukar tanda pada tabung gas.

- Penggunaan gas harus selalu lewat regulator.

- Janganlah menarik tutup pengaman pada saat mengangkat atau mengalihkan tabung gas.

- Jika terjadi kebocoran tabung gas, selekasnya bawa keluar ruangan.

2. Regulator

Regulator terpasang di masing-masing tabung oksigen untuk mengendalikan keluarnya gas dari dalam tabung ke arah pembakar lewat selang las. Regulator mempunyai dua buah manomenter untuk memahami desakan isi gas di tabung yang dimaksud manometer desakan isi. Manometer desakan kerja untuk lihat desakan kerja yang digunakan mengelas. Aksi pengamanan alat ini mencakup:

- Tangan atau sarung tangan harus dibersihkan dari minyak atau pelumas sebelum menggenggam regulator.

- Waktu menempatkan regulator, sisi yang perlu dipegang ialah badan regulator bukan pada manometernya.

- Katup regulator mesti dalam kondisi tertutup waktu akan membuka kran tabung. Langkah membuka katup regulator dikerjakan dengan memutar baut pengendali bersimpangan arah jarum jam sampai longgar.

- Putar baut pengendali tekanan kerja dengan perlahan-lahan waktu mengendalikan tekanan kerja supaya tidak mengakibatkan kerusakan membran manometer.

- Waktu dikerjakan penyusunan desakan kerja pada regulator, posisi badan berdiri di samping.

3. Pembakar

Pembakar dipakai untuk mencampurkan gas oksigen serta gas asetilin dengan perbandingan spesifik sesuai dengan kepentingan kerja. Pembakar terbagi dalam dua jenis yakni pembakar pengelasan biasa serta pembakar pemotongan. Mekanisme keselamatan kerja memakai pembakar ialah:

- Pembakar tidak bisa disentuh atau dipegang oleh tangan atau sarung tangan yang terkena minyak atau pelumas.

- Tidak diperbolehkan memakai mulut pembakar untuk mencungkil atau memukul sebab kerusakan pada mulut pembakar bisa mengakibatkan nyala balik. 
- Membersihkan mulut pembakar dari kotoran yang menyumbat dengan berkala memakai alat penusuk spesial.

- Bibir mulut pembakar harus dibersihkan dari kotoran dengan memakai bilah kayu lunak sekalian membuka kran tabung oksigen.

- Mematikan api yang menyala dari pembakar jika tidak digunakan.

- Untuk memperoleh hasil kerja yang baik, taruh dan rawatlah pembakar dengan benar serta teratur.

4. Selang

Dipergunakan untuk pengelasan dapat dikenal dengan mudah, warna biru atau hijau untuk gas asam dan warna merah untuk gas asetilin.Panjang selang minimal $5 \mathrm{~m}$, dengan menggunakan klem ganda. Mengikat kedua selang dengan jarak satu dengan yang lain 1 $\mathrm{m}$, sehingga dalam melakukan pekerjaan terlihat rapi dan aman.

5. Tempat kerja

Terdiri atas meja yang permukaan sebagai dari batu tahan api dan bagian lain dari besi siku posisi tengkurap. Di sebelah depan terletak tempat air untuk pendingin ujung pembakar, sebelah kiri terletak tempat bahan tambah, tiang untuk penjepit benda kerja dan di sebelah kanan terletak tempat untuk meletakkan/menggantung pembakar.

6. Pakaian kerja

Di dalam pekerjaan las gas diperlukan pakaian kerja yang dilindungi dari api dengan pelindung dari kelit (Apron). Adapun guna dari pelindung yang terbuat dari kulit yaitu tidak akan menembus kepakaian dan ke badan karena percikan-percikan api dari ujung pembakar. Serta jangan lupa menggunakan pelindung untuk sepatu, karena kalau percikan sampai masuk ke dalam sepatu, maka akan dibuat sesuatu olehnya dan akan mengurangi konsentrasi dalam pekerjaan.

\section{HASIL DAN PEMBAHASAN}

Bagi kampus Institut Teknologi Nasional Malang kegiatan ini merupakan wujud nyata partisipasi dunia pendidikan dalam pengabdian kepada masyarakat melalui pendidikan dan pelatihan maupun penerapan teknologi sehingga masyarakat dapat memanfaatkannya dalam menjalankan usahanya.

\section{KESIMPULAN DAN SARAN}

\section{Kesimpulan}

Pelatihan ini dirancang sedemikian rupa sehingga mudah dipahami oleh anak-anak yang 
diharapkan bisa mengikuti bahan pelatihan dengan mudah dan tidak merasa kesulitan.

1. Meningkatkan wawasan/ilmu terhadap anak putus sekolah tentang proses pengelasan.

2. Dapat terciptanya usaha mandiri oleh anak putus sekolah.

Setelah mengikuti kegiatan ini, anak-anak putus sekolah mampu membuat produk usaha mandiri yang memiliki kualitas unggul dimana semua anggotanya juga memiliki semangat yang tinggi dalam berkarya.

\section{Saran}

Hendaknya pelatihan ini dilakukan dengan terstruktur. Agar anak-anak putus sekolah diharapkan dapat menghasilkan produk dengan lebih baik tanpa adanya hambatan.

\section{DAFTAR PUSTAKA}

Fatchurahman, A. 2011. Pengelasan Oksi Asetilin, Academia. Shaury, A. 2017. Makalah Teknik Las Tabung Gas Oksigen dan Asitelin.

Surdia, T. dan Saito, S. 1984. Pengetahuan Bahan Teknik. Jakarta: Pradnya Paramita. Undang-Undang No 4 Tahun 1979 tentang Kesejahteraan Anak.

Wiryosumarto, H. dan Okumura, T. 2000. Teknologi Pengelasan Logam. Jakarta. 